University of Nebraska - Lincoln

DigitalCommons@University of Nebraska - Lincoln

\title{
Isotopic signature of burial diagenesis and primary lithological contrasts in periplatform carbonates (Miocene, Great Bahama Bank)
}

Tracy D. Frank

University of Nebraska-Lincoln, tfrank2@unl.edu

Karin Bernet

University of Miami

Follow this and additional works at: https://digitalcommons.unl.edu/geosciencefacpub

Part of the Earth Sciences Commons

Frank, Tracy D. and Bernet, Karin, "Isotopic signature of burial diagenesis and primary lithological contrasts in periplatform carbonates (Miocene, Great Bahama Bank)" (2000). Papers in the Earth and Atmospheric Sciences. 110.

https://digitalcommons.unl.edu/geosciencefacpub/110

This Article is brought to you for free and open access by the Earth and Atmospheric Sciences, Department of at DigitalCommons@University of Nebraska - Lincoln. It has been accepted for inclusion in Papers in the Earth and Atmospheric Sciences by an authorized administrator of DigitalCommons@University of Nebraska - Lincoln. 


\title{
Isotopic signature of burial diagenesis and primary lithological contrasts in periplatform carbonates (Miocene, Great Bahama Bank)
}

\author{
Tracy D. Frank \\ Department of Earth Sciences, University of Queensland, St Lucia, QLD 4072, Australia \\ Karin Bernet \\ Comparative Sedimentology Laboratory, University of Miami, Miami, FL 33149, USA
}

\begin{abstract}
The stable isotope geochemistry of Miocene sediments from the leeward margin of the Great Bahama Bank was examined to investigate burial diagenetic processes in periplatform carbonates. Data indicate that, in addition to differences in bulk proportions of neritic and pelagic carbonate along the slope, rhythmic variation in primary carbonate content has controlled patterns of burial diagenesis and associated geochemical signatures throughout much of the succession examined. The present study focuses on Ocean Drilling Program Sites 1006 and 1007, the most distal of five sites drilled from marginal to deep basin environments during Leg 166. These Miocene sections are characterized by their cyclic appearance, manifest as decimeter- to meter-scale alternations between light-colored ooze/chalk/limestone and dark-colored marl/marlstone. The section at Site 1006 contains a high proportion of pelagic carbonate and is unlithified to a subbottom depth of $\sim 675 \mathrm{~m}$. Fluctuations in $\delta^{18} \mathrm{O}$ and $\delta^{13} \mathrm{C}$ values at this site are independent of lithological variation and reflect primary conditions. At Site 1007, located at the toe-of-slope and composed of a mixture of bank-derived and pelagic carbonate, limestones are densely cemented, show little evidence of compaction and have $\delta^{18} \mathrm{O}$ values up to $2 \%$ higher than coeval sediments at Site 1006. Marlstones at Site 1007 are poorly cemented, exhibit an increase in compaction-related features with depth and have lower and more variable $\delta^{18} \mathrm{O}$ values that are similar to those of coeval sediments at Site 1006. Isotopic and petrographic characteristics of limestone interbeds result from cement precipitation from cold sea water during the first $\sim 100 \mathrm{~m}$ of burial. Higher proportions of insoluble materials and pelagic carbonate seem to have inhibited diagenetic alteration in adjacent marlstones; in spite of significant compaction and pressure solution during burial, original isotopic compositions appear to be best preserved in these intervals at Site 1007. The documented contrasts in petrographic and isotopic patterns illustrate the role of primary sediment composition in controlling lithification processes in periplatform carbonates and stress the importance of considering such factors when interpreting geochemical data from ancient shelf and slope limestones.
\end{abstract}

Keywords: Carbonate diagnosis, carbon isotope cyclicity, oxygen isotope, periplatform

\section{Introduction}

Periplatform carbonates accumulate adjacent to carbonate platforms in an environment that is transi- tional between the shallow and deep marine realms. The transitional nature of this depositional setting is reflected in the composition of periplatform sediments, which consist of mixtures of platform-derived 
components, composed primarily of aragonite and high-Mg calcite, and pelagic ooze made up principally of low-Mg calcite (Schlager \& James, 1978). Recognition that periplatform carbonate sediments undergo an accelerated ooze/chalk/limestone transition relative to pelagic counterparts and possess geochemical and textural characteristics that mimic meteoric diagenesis (Mullins et al., 1985; Dix \& Mullins, 1988a,b; Melim et al., 1995) has generated considerable interest, because the timing, rate and extent of early subsurface lithification affect slope stability, margin development and, ultimately, the character and regional distribution of porosity and cement in carbonate platforms (Dix \& Mullins, 1992). Most current knowledge concerning the diagenesis of periplatform sediments has emerged from the examination of Pliocene-Holocene carbonates and/or associated pore waters in seafloor outcrops (Schlager \& James, 1978), shallow piston cores ( $<12 \mathrm{~m}$; Mullins et al., 1985) and the upper $\sim 250 \mathrm{~m}$ of cores drilled to deeper depths (e.g. Dix \& Mullins, 1988a,b, 1992; Swart \& Guzikowski, 1988; Malone et al., 1990; Swart \& Burns, 1990; Melim et al., 1995; Westphal, 1998). These studies have revealed significant heterogeneity in rates of subsurface lithification and calcitization as a function of primary sediment composition, sedimentation rate and ambient sea-water chemistry.

Although studies of deep-sea calcareous oozes long formed the basis for interpreting the formation of many Paleozoic shelf and slope limestones, periplatform sediments probably provide a more appropriate modern analogue (Schlager \& James, 1978). Owing to the absence of calcareous planktonic protists in the pre-Mesozoic record, many Paleozoic deposits that have been subjected to deep burial presumably formed initially by the accumulation, calcitization and lithification of primarily platform-derived carbonate in shallow, subsiding marine basins. Because previous diagenetic studies of Neogene periplatform sediments are largely restricted to shallow burial settings $(<250 \mathrm{~m})$, little is known regarding the extent to which shallow diagenetic processes influence further textural and chemical alteration during deeper burial in the marine environment. As such, it is difficult to distinguish features in ancient examples related to shallow subsurface processes from those associated with deep burial diagenesis (e.g. Mazzullo, 1994; Hendry et al., 1996).

The present study attempts to establish a link between shallow subsurface processes documented in modern periplatform settings and geochemical and petrographic characteristics of ancient counterparts that have undergone significant burial. Specifically, we compare and contrast stable isotopic and petrographic patterns in Miocene sections recovered at two sites along the leeward margin of the Great Bahama Bank (GBB) during Ocean Drilling Program (ODP) Leg 166. Miocene sediments at each site examined were buried to depths in excess of $300 \mathrm{~m}$ below the sea floor (mbsf). Site 1007, the most proximal of the two, is located at the toe-of-slope of the GBB and contains a relatively high proportion of bank-derived components (Eberli et al., 1997). The Miocene section at this site is fully lithified, and compactional processes have led to the development of dissolution seams and anastomosing stylolites below 1120 mbsf. In contrast, the section at Site 1006, situated in Neogene current drift deposits in the Straits of Florida and composed primarily of pelagic carbonate, is not fully lithified until $\sim 675$ mbsf (Eberli et al., 1997). Given intersite contrasts associated with position along the carbonate slope, the Miocene sections examined provide an ideal context within which to investigate the influences of initial sediment composition and shallow subsurface diagenetic processes on petrographic and isotopic patterns in periplatform successions that have entered the deep burial diagenetic realm.

\section{Depositional Setting}

Sites 1006 and 1007 are the most distal of seven sites drilled to complete the Bahamas Transect, which extends from marginal to deep basin environments on the leeward side of the GBB (Figure 1; Eberli et al., 1997). Site 1007 is located on the toe-of-slope in approximately $647 \mathrm{~m}$ of water. A nearly continuous $~ 900-\mathrm{m}-$ thick Miocene section was recovered at this site, which consists of a succession of bioturbated, periplatform limestone with interbeds of turbiditic packstone, grainstone and floatstone (Figure 2; Eberli et al., 1997). Site 1006, the most distal site along the Bahamas Transect, was drilled approximately $30 \mathrm{~km}$ from the platform edge of the GBB in $658 \mathrm{~m}$ of water. Approximately $334 \mathrm{~m}$ of middle and upper Miocene sediments were recovered at this site, which is positioned in a nearly continuous sequence of Neogene current drift sediments that onlap and interfinger with prograding bank slope deposits (Eberli et al., 1997). Owing to its more distal location, the Miocene section at Site 1006 contains 

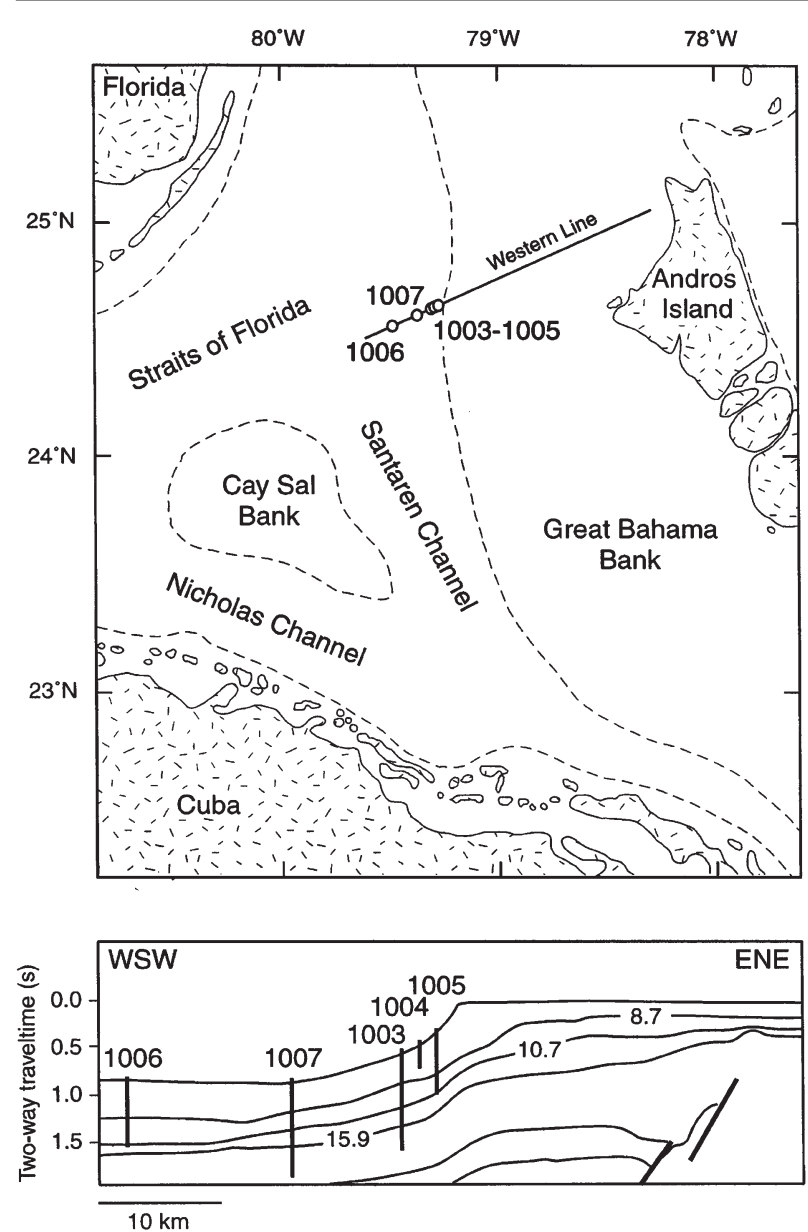

Figure 1. Location map (top) and schematic seismic profile (bottom; after Eberli et al., 1997) showing locations of sites drilled on the leeward margin of the Great Bahama Bank during Ocean Drilling Program Leg 166. Sites 1003-1007 were drilled along a seismic line (Western Line) originally acquired by Western Geophysical. Dashed lines on location map (top) indicate $200 \mathrm{~m}$ contour. Numbers on selected seismic reflectors (bottom) correspond to age in millions of years.

relatively few turbiditic deposits, has a significantly lower neritic component and consists primarily of nanofossil ooze and chalk with variable amounts of admixed silt and clay (Figure 2). Benthic foraminiferal assemblages at Sites 1006 and 1007 suggest that deposition during the Miocene occurred in water depths between 600 and $800 \mathrm{~m}$, roughly similar to the upper middle bathyal depths in which the sites are currently located (Eberli et al., 1997).

A striking feature of the Miocene section along the leeward slope of the GBB is a nearly ubiquitous, decimeter- to meter-scale alternation between relatively light-colored ooze/chalk/limestone and relatively dark-colored marl (Figure 3). The dark-light color changes correspond to differences in the relative

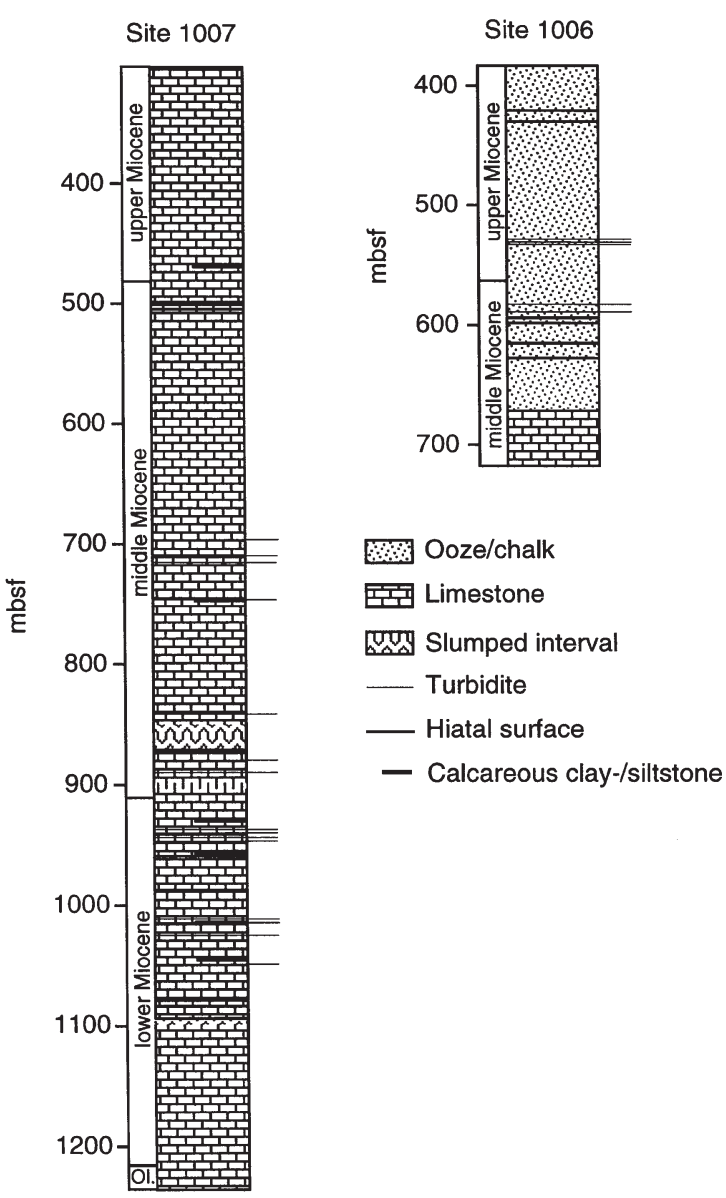

Figure 2. Stratigraphy of Miocene sediments penetrated at Sites 1006 and 1007.

bulk concentrations of carbonate, clay and organic carbon among dark-light interbeds. Light-colored oozes/ chalks/limestones typically have higher carbonate and lower clay and organic carbon contents, whereas darkcolored marls/marlstones have lower carbonate and higher clay and organic carbon contents. Petrographic analysis reveals that contrasts in carbonate and clay concentrations correspond to variations in the relative proportions of pelagic and platform-derived carbonate, in which carbonate-rich interbeds contain a higher proportion of components shed from the platform top than do carbonate-poor beds (Bernet, 1999). At Site 1007, the differences within each dark-light couplet are accentuated further by differences in degrees of lithification and compaction (Figure 3). Bioturbated limestones that make up the light-colored halves of the dark-light couplets generally contain a higher proportion of shallow-water components (Bernet, 1999), tend to be densely cemented and exhibit little evidence of compaction (Eberli et al., 1997). Conversely, greenishgrey marlstones that comprise the dark halves of the 


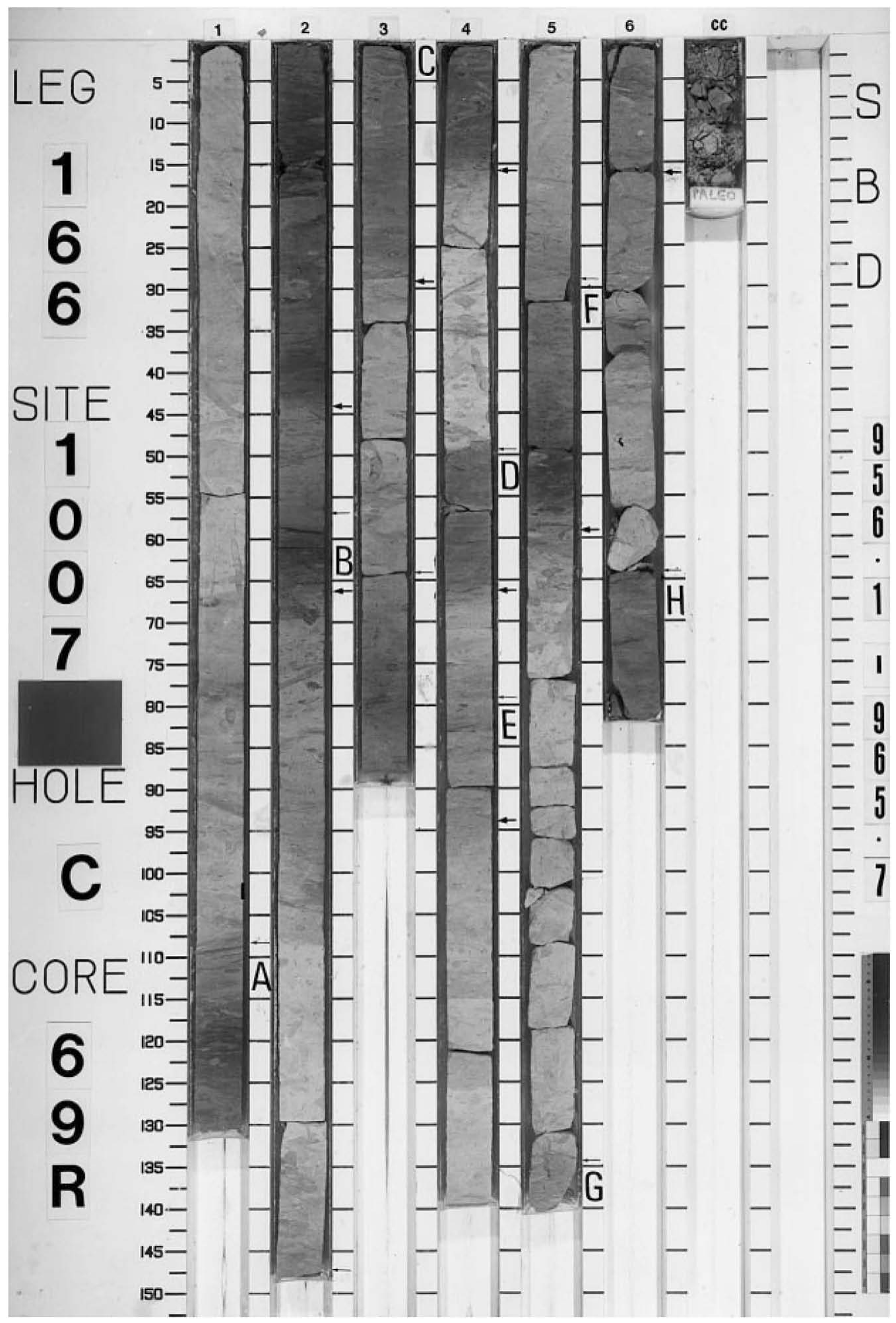

Figure 3. Photograph of Core 166-1007C-69R (956-1-965.7 mbsf) showing alternating interbeds of light-colored limestone and dark-colored marlstone that characterize Miocene sections recovered during Leg 166. Scale on the left side of the photograph is in cm. Numbers 1-6 and CC (core catcher) across the top of the photograph refer to sections; top of core is at upper left (section 1), base of core is at bottom right (section CC). Age is early Miocene. Arrows to the right of each core section indicate tops (light arrows) and bottoms (heavy arrows) of marlstone intervals A-H in which bioturbation structures have been flattened by compaction. 
couplets contain a higher proportion of pelagic materials (Bernet, 1999) and are typically poorly cemented and highly compacted, with the degree of compaction increasing downcore (Eberli et al., 1997).

Bedding rhythmicity, manifest as cyclic interbeds of more and less calcareous lithologies, is a pronounced characteristic of many Mesozoic and Cenozoic pelagic sections that have been recovered from deep-sea sites in the North Atlantic (e.g. Dean et al., 1978; Jansa et al., 1979; Dean \& Gardner, 1982; Cotillon \& Rio, 1984; Arthur et al., 1984; Dean \& Arthur, 1987; Arthur \& Dean, 1991; Cotillon, 1991). A range of mechanisms has been proposed to account for such cyclicity (see reviews by Einsele, 1982; Arthur et al., 1984; Ricken, 1992), including: (1) cyclic change in shallow-water carbonate productivity; (2) fluctuation in the input of non-carbonate material; (3) variation in water depth and/or depositional energy that favors alternating deposition and non-deposition of carbonate and differential early diagenesis; and (4) early diagenetic differentiation of carbonate into discrete layers, which may be independent of any primary variation in carbonate content. Pinpointing an exact mechanism behind the development of cyclic patterns in Miocene sediments of the GBB is beyond the scope of the present study. However, the ubiquitous presence of dark-light couplets throughout the section and especially at Site 1006, where sediments remain unlithified to great depth, and contrasts in the relative proportions of neritic and pelagic allochems between adjacent interbeds suggest that the cyclicity reflects primary depositional processes and/ or environmental conditions and cannot be attributed solely to diagenesis.

\section{Methods}

Bulk sediment samples $\left(\sim 10-20 \mathrm{~cm}^{3}\right)$ were collected aboard the JOIDES Resolution during ODP Leg 166. A representative range of lithologies from the Miocene sections at Sites 1006 and 1007 was chosen at semi-regular intervals ( $\sim$ two samples per $1.5 \mathrm{~m}$ section of core) on the basis of core descriptions and visual observations. In addition, suites of samples were taken from three detailed transects across cyclic couplets in cores 69R and 70R from Site 1007, Hole C, and in Core 55X from Site 1006, Hole A. Approximately one-quarter of each bulk sample was air dried at $75^{\circ} \mathrm{C}$ in an oven and powdered; in cases in which individual sediment sam- ples cross-cut the boundary between adjacent darklight intervals, an equivalent amount of each lithology was prepared. Bulk powders were analyzed for total carbon and total inorganic $\left(\mathrm{CaCO}_{3}\right)$ carbon contents, carbonate mineralogy and carbon and oxygen isotope compositions. The selective removal and analysis of individual petrographic components in Site 1007 samples was precluded by dense cementation and their fine-grained nature. Selected bulk samples from Site 1006 were disaggregated, and well-preserved benthic foraminifera (Cibicidoides sp.) were picked from the 250-354 $\mu \mathrm{m}$ size fraction for isotopic analysis. Isotopic ratios are reported in \%o relative to the Vienna Peedee belemnite (PDB) standard. Geochemical data and a detailed review of analytical methods are available in Frank (2000).

\section{Patterns In Geochemical Data}

\section{Carbonate mineralogy}

The carbonate mineralogy at Sites 1006 and 1007 is dominated by low-Mg calcite with lesser amounts of aragonite and dolomite (Figure 4). No high-Mg calcite was detected in Miocene sediments recovered during Leg 166. The absence of this phase may either reflect the effects of the carbonate ramp depositional setting and differences in climate on shallow-water carbonate production during the Miocene (Eberli \& Ginsburg, 1989) or the susceptibility of high-Mg calcite to alteration in deep, cold sea water (Schlager \& James, 1978). At Site 1007, aragonite generally makes up less than $10 \mathrm{wt} \%$ of the total carbonate (Figure $4 \mathrm{~A}$ ), although elevated levels of aragonite (up to $40 \mathrm{wt} \%$ ) are encountered in dark-colored intervals characterized by increased concentrations of acid-insoluble residues, including organic matter, clay and silt (Figure 4B). No aragonite was detected below $\sim 1000$ mbsf at Site 1007. Petrographic observations demonstrate that originally aragonitic skeletal components (e.g. Halimeda, pteropods, corals and bivalves) in limestone interbeds at this site were dissolved and, in most cases, replaced by calcite spar (Bernet, 1999). Smear-slide analyses performed during Leg 166 suggest that the main source of aragonite in carbonate-poor intervals is aragonitic mud derived from the platform top (Eberli et al., 1997).

Although petrographic analyses indicate a higher proportion of platform-derived components at Site 


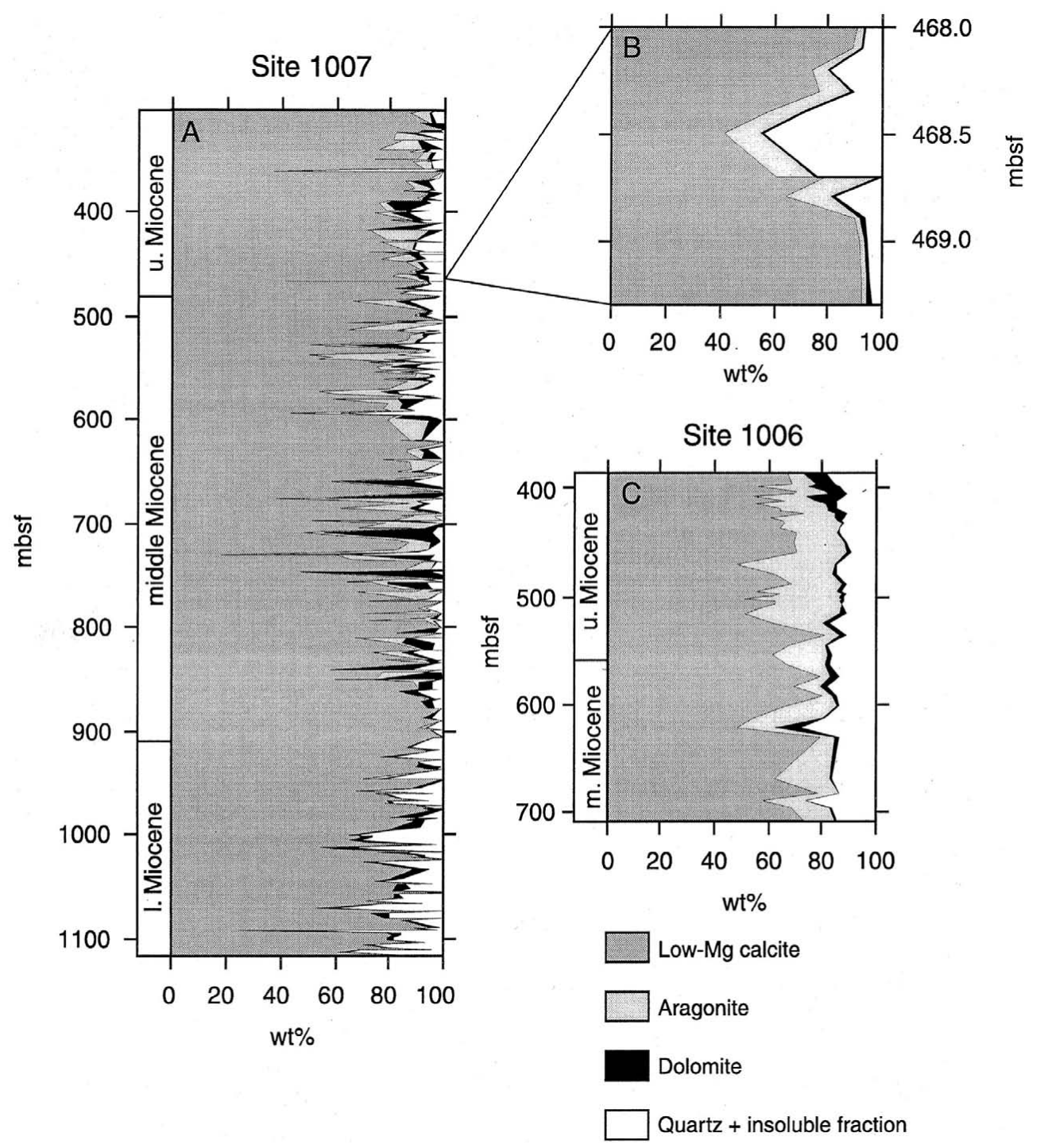

Figure 4. Quantitative X-ray mineralogy of Miocene sediments from Site 1007 (A) and Site 1006 (C). (B) Detail of variation in carbonate mineralogy across a transition over $\approx 1.5 \mathrm{~m}$ at Site 1007 from the top of a limestone bed ( $\approx 469.5-468.7 \mathrm{mbsf})$, through an overlying marlstone interbed ( $\approx 468.7-468.2 \mathrm{mbsf}$ ) to the bottom of a second limestone bed (above $\approx 468.2 \mathrm{mbsf}$ ); aragonite concentration increases with increasing quartz and insoluble concentrations. Total $\mathrm{CaCO}_{3}$ content is equivalent to the following sum: $w t \%$ low-Mg calcite $+w t \%$ aragonite $+w t \%$ dolomite. Data are from the present study and shipboard analyses by Eberli et al. (1997).

1007, higher average aragonite concentrations were measured at Site 1006 (Figure 4C). Aragonite contents at Site 1006 are relatively uniform and show little correlation with clay and organic matter contents. Concentrations range from 15 to $35 \mathrm{wt} \%$ between 450 and $550 \mathrm{mbsf}$ and decrease to less than $15 \mathrm{wt} \%$ at greater depths. More uniform and higher average aragonite concentrations at Site 1006 relative to Site 1007 are probably the result of a slower rate of diagenetic alteration on distal parts of the slope affected by a preponderance of pelagic deposition relative to more proximal regions where metastable, platform-derived components accumulate at a higher rate (e.g. Malone et al., 1990).

\section{Carbon coulometry}

Throughout the Miocene sections examined, variation in carbonate content corresponds to the cyclic color changes that characterize these sections (Figure 5). In general, lighter intervals have higher $\mathrm{CaCO}_{3}$ and lower clay and organic carbon contents, whereas darker intervals have lower $\mathrm{CaCO}_{3}$ and higher clay and organic carbon contents. Compositional contrasts 

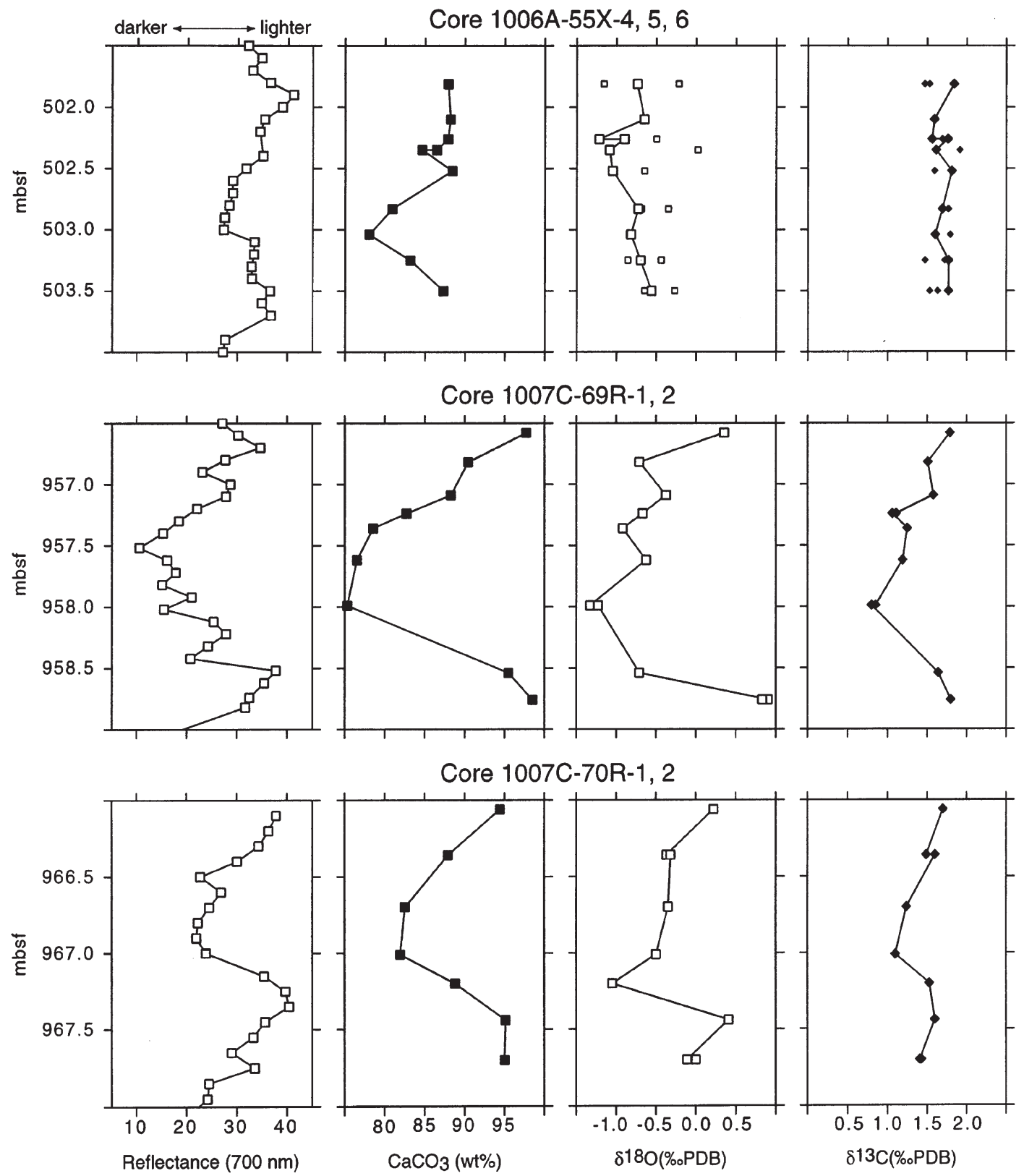

Figure 5. Detailed sampling transects through adjacent dark-light interbeds at Site 1006 (top; core 166-1006A-55X-4, 5, 6) and Site 1007 (middle, core 166-1007C-69R-1, 2; see also Figure 3; bottom, core 166-1007C-70R-1, 2). Plots from left to right show variation in color (reflectance), $\mathrm{CaCO}_{3}$ content, $\delta^{18} \mathrm{O}$ values and $\delta^{13} \mathrm{C}$ values along each transect. Oxygen and carbon isotope compositions of the benthic foraminifer Cibicidoides sp. from Site 1006 (top) are represented by small symbols.

among adjacent interbeds are more pronounced at Site 1007 than at Site 1006 (Figs 4 and 5). At Site 1007, $\mathrm{CaCO}_{3}$ contents range between $\sim 60$ and $100 \mathrm{wt} \%$ and exhibit slightly more variation in the lower Miocene section relative to the middle and upper Miocene sections (Figure 4). Carbonate contents at Site 1006, on the other hand, are comparatively uniform; $\mathrm{CaCO}_{3}$ concentrations never reach $100 \mathrm{wt} \%$ and, with minor exceptions, tend to fall within a relatively narrow range of $\sim 80-90 \mathrm{wt} \%$ (Figure 4).

\section{Stable isotope data}

Whole-rock carbonate samples from Sites 1006 and 1007 exhibit significant stratigraphic variation in carbon and oxygen isotope composition (Figure 6). At Site $1007, \delta^{18} \mathrm{O}$ values decrease downcore from values as high as $2.1 \%$ at 370 mbsf to values ranging between $-0.7 \%$ and $0.8 \%$ at $\sim 950$ mbsf. Below this interval, $\delta^{18} \mathrm{O}$ values increase progressively to values as high as $1.4 \%$ at $\sim 1230$ mbsf. Carbon isotope compositions at 


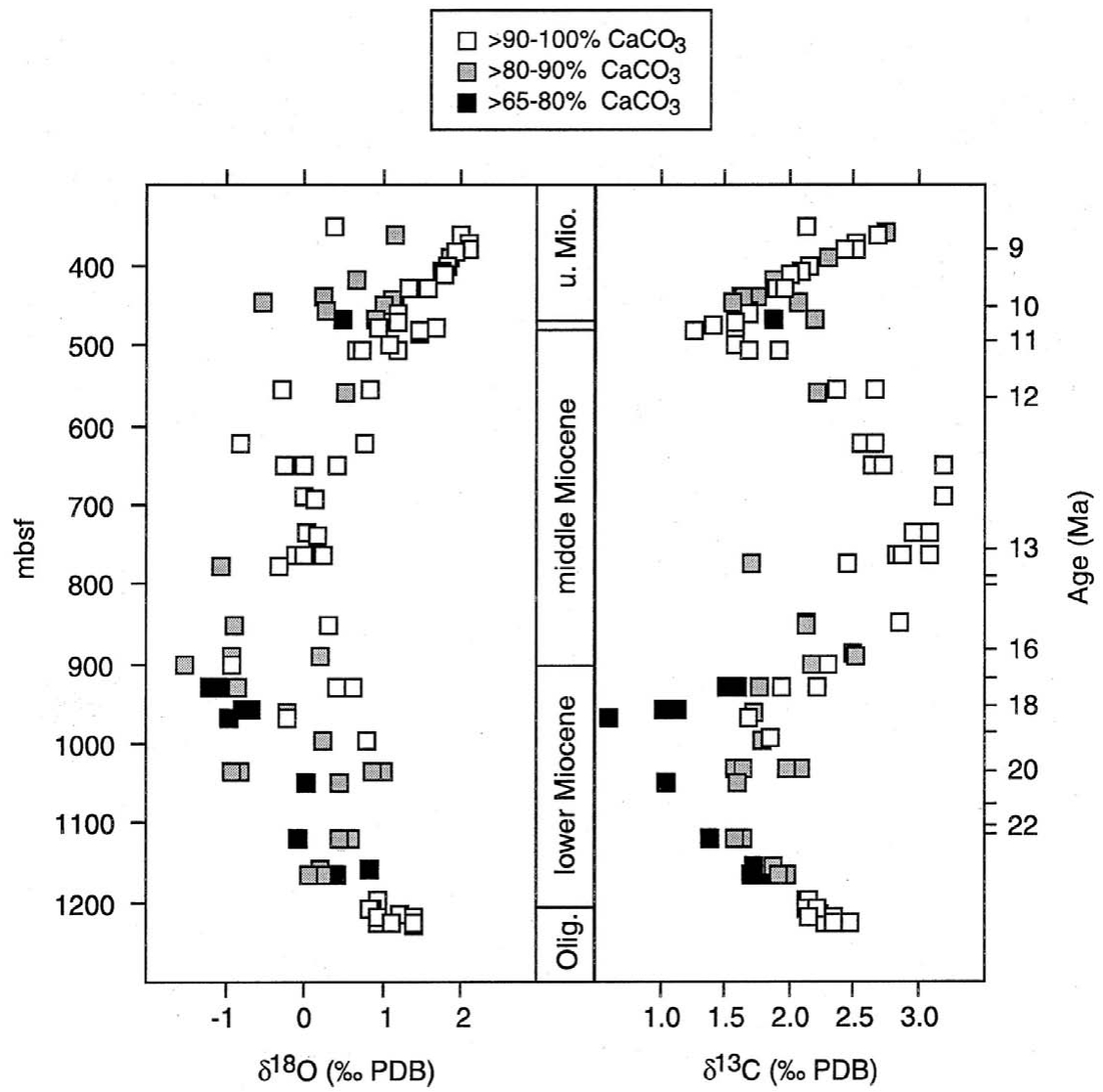

Figure 6. Downcore variability in $\delta^{18} \mathrm{O}$ and $\delta^{13} \mathrm{C}$ values of whole-rock samples in the Miocene section at Sites 1006 and 1007.
Site 1007 exhibit a total range of nearly $2.5 \%$ ond vary systematically downcore (Figure 6). The $\delta^{13} \mathrm{C}$ values decrease sharply from values of $\sim 2.7 \%$ near the top of the section examined to values ranging from $\sim 1.2-$ $2.3 \%$ at $\sim 500 \mathrm{mbsf}$. The $\delta^{13} \mathrm{C}$ values increase continuously downcore to $\sim 3.1 \%$ o at $\sim 750$ mbsf. Between $\sim 750$ and $1050 \mathrm{mbsf}$, samples exhibit a second downcore decrease in $\delta^{13} \mathrm{C}$ values. Below this interval, $\delta^{13} \mathrm{C}$ values increase progressively to values as high as $2.5 \%$ at the base of the section. At Site $1006, \delta^{18} \mathrm{O}$ values exhibit a range of nearly $2.5 \%$, and $\delta^{13} \mathrm{C}$ values decrease by $\sim 1 \%$ with increasing depth (Figure 6). Although samples at Sites 1006 and 1007 exhibit a similar variation in carbon isotope composition, $\delta^{18} \mathrm{O}$ values of Site 1006 samples are generally lower than those of Site 1007 samples (Figure 6). A comparison of variation in isotopic composition with age at Sites 1006 and 1007 (Figure 7) reveals that $\delta^{18} \mathrm{O}$ values of Site 1007 samples are as much as $2 \%$ o higher than the values of contemporaneous sediments at Site 1006. Carbon isotope compositions of coeval Site 1006 and 1007 sediments, on the other hand, are virtually identical (Figure 7). At Site $1007, \delta^{18} \mathrm{O}$ values tend to increase with increasing $\mathrm{CaCO}_{3}$ content (Figure 6). Because of stratigraphic variation in oxygen isotope composition, the relationship between $\delta^{18} \mathrm{O}$ values and $\mathrm{CaCO}_{3}$ at Site 1007 is most apparent when examined at the scale of individual cycles (Figure 5); $\delta^{18} \mathrm{O}$ values of adjacent limestone and marlstone intervals vary by as much as $2 \%$. Carbon isotope compositions at Site 1007 do not appear to vary as extensively with $\mathrm{CaCO}_{3}$ content, but carbonatepoor intervals tend to be relatively depleted in ${ }^{13} \mathrm{C}$ (Figure 5). In contrast, neither $\delta^{18} \mathrm{O}$ nor $\delta^{13} \mathrm{C}$ values appear to vary as a function of $\mathrm{CaCO}_{3}$ at Site 1006 (Figure 5).

Because Middle and Upper Miocene sediments at Site 1006 are poorly lithified and contain significant amounts of aragonite, the $\delta^{18} \mathrm{O}$ values of these sediments should reflect more faithfully the character of Miocene surface waters in which the calcareous nanofossils and planktonic foraminifers that make up the bulk of the sediments grew. Preservation of primary signals at Site 1006 is further supported by the retention of expected differences in $\delta^{18} \mathrm{O}$ values associated with surface to deep-water temperature gradients recorded in whole-rock samples, made up primarily of surface-dwelling calcareous nanoplankton and tests of the benthic foraminifer Cibicidoides sp. Although measured carbon and oxygen isotope compositions of nanoplankton tests may incorporate variable vital effects, Cibicidoides sp. are known to precipitate shells with $\delta^{18} \mathrm{O}$ values consistently $0.64 \%$ o below the value of equilibrium calcite (Shackleton \& Opdyke, 1973; Gra- 
Figure 7. Miocene oxygen (left) and carbon (right) isotope stratigraphies of whole-rock samples from Site 1007 (open squares), whole-rock samples from Site 1006 (open circles), the benthic foraminifer Oridorsalis umbonatus from Deep Sea Drilling Project (DSDP) Site 216 in the tropical Indian Ocean (filled squares) and the benthic foraminifer Cibicidoides spp. from DSDP Site 563 in the western North Atlantic (crosses). Data from Site 216 are from Vincent \& Berger (1985), and data from Site 563 are from Miller \& Fairbanks (1985). Sample ages are calibrated to the geomagnetic polarity timescale of Berggren et al. (1995).

ham et al., 1981). Taking the offset from equilibrium $\delta^{18} \mathrm{O}$ values into account, "equilibrium" benthic foraminifera $\delta^{18} \mathrm{O}$ values from Site 1006 are consistently $\sim 1-1.5 \%$ o higher than whole-rock $\delta^{18} \mathrm{O}$ values (Figure 5, top). As such, the direction of the offset is consistent with warmer surface water overlying cooler deep water. In contrast, trends of increasing $\delta^{18} \mathrm{O}$ value with increasing $\mathrm{CaCO}_{3}$ content at Site 1007 suggest that the rhythmic variation in lithology that characterizes the Miocene succession of the western GBB has played a role in governing the processes of burial diagenesis at this site.

\section{Discussion}

\section{Lithological control on diagenesis}

Ignoring any possible vital effects on isotopic composition, the apparent retention of primary isotopic compositions at Site 1006 suggests that conditions that led to decimeter- to meter-scale cyclic sedimentation along the western slope of the GBB did not produce significant corresponding variations in primary $\delta^{18} \mathrm{O}$ and $\delta^{13} \mathrm{C}$ values. Given this assumption, trends of increasing $\delta^{18} \mathrm{O}$ values with increasing $\mathrm{CaCO}_{3}$ content at Site 1007 suggest that compositional differences among cyclic interbeds have, however, influenced the extent of diagenesis and overprinting of primary isotopic signatures in more proximal sections that are fully lithified. Application of the calcite-water oxygen isotope fractionation equation $\left[10^{3} \ln \alpha=\left(2.78 \times 10^{6}\right) \mathrm{T}^{-2}-2.89\right]$ of Friedman \& O'Neil (1977) indicates that $\delta^{18} \mathrm{O}$ values up to $2 \%$ o higher from carbonate-rich intervals at Site 1007 relative to values from Site 1007 marlstones (Figs 5 and 6) and coeval sediments at Site 1006 (Figure 7) are consistent with calcite formation at temperatures up to $10^{\circ} \mathrm{C}$ cooler. Such a temperature gradient is larger than current differences in seafloor temperature between Sites 1006 and 1007 (Eberli et al., 1997) and too large to be reasonably related to cyclic temperature fluctuations at Site 1007. A more reasonable scenario involves overprinting of primary $\delta^{18} \mathrm{O}$ values in Site 1007 limestones by calcitization and cementation in the presence of cold sea water, presumably either on the seafloor or at shallow burial depths. Conversely, lower $\delta^{18} \mathrm{O}$ values in adjacent marlstone interbeds that approach values in unlithified sediments at Site 1006 suggest that, despite the effects of burial solution and compaction, primary carbonate in Site 1007 marlstones has not been significantly altered.

Sedimentological and petrographic observations are consistent with this interpretation. Throughout the Miocene section at Site 1007, limestone interbeds are densely cemented (Figure 8A) and show little evidence of compactional volume loss with depth. Burrow crosssections retain their original (round) shapes (Figure 3), and delicate skeletal grains (i.e. planktonic foraminiferal tests) remain unbroken to great depth (Figure $8 \mathrm{~B}$ ). The preservation of such features suggests that carbonate-rich intervals at Site 1007 have undergone some degree of early lithification. Bioturbation structures in adjacent marlstones, in contrast, are often flattened (intervals A-H in Figure 3), indicating that early lithifica- 

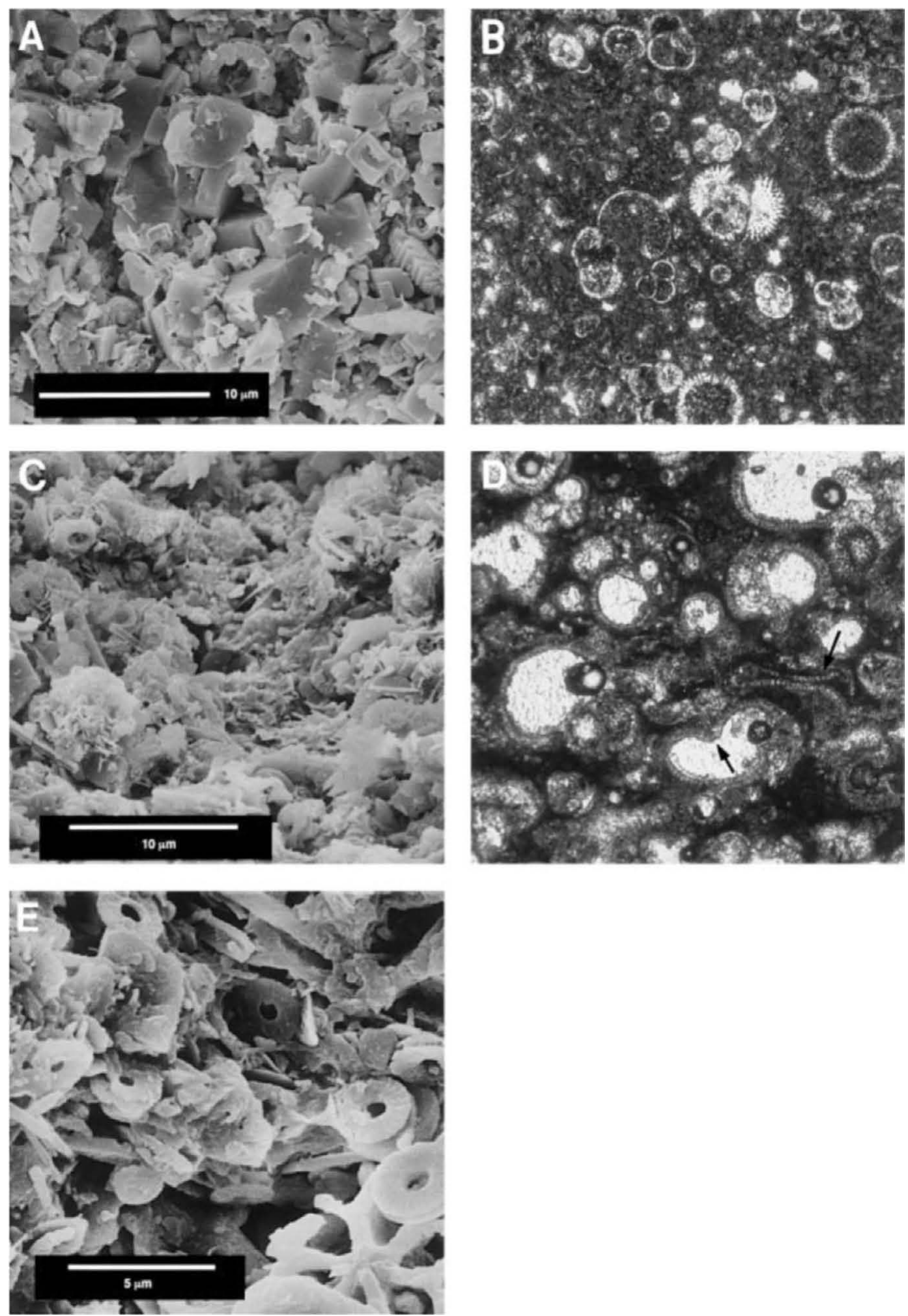

Figure 8. (A) SEM and (B) plane light (width $1.33 \mathrm{~mm}$ ) photomicrographs of a carbonate-rich interval $\left(95.1 \mathrm{wt} \% \mathrm{CaCO}_{3}\right.$ ) at 930.23 mbsf (Core 166-1007C-66R-3, 30-33 cm). Blocky calcite cement occurs throughout the fine-grained matrix and fills intraparticle pore space. (C) SEM and (D) plane light (width $1.33 \mathrm{~mm}$ ) photomicrographs illustrating the character of a carbonate-poor interval $\left(77.8 \mathrm{wt} \% \mathrm{CaCO}_{3}\right.$ ) at $930.25 \mathrm{mbsf}$ (Core 166-1007C-66R-3, 12-15 cm), adjacent to the interval depicted in (A) and (B). Cement is rare, intraparticle pore space is empty, and skeletal grains show evidence of compactional deformation. Crushed grains are denoted by arrows in (D). (E) SEM photomicrograph of unlithified pelagic sediments at Site 1006 (Core 166-1006A-55X-5, 74-76 cm; $503.05 \mathrm{mbsf})$. 


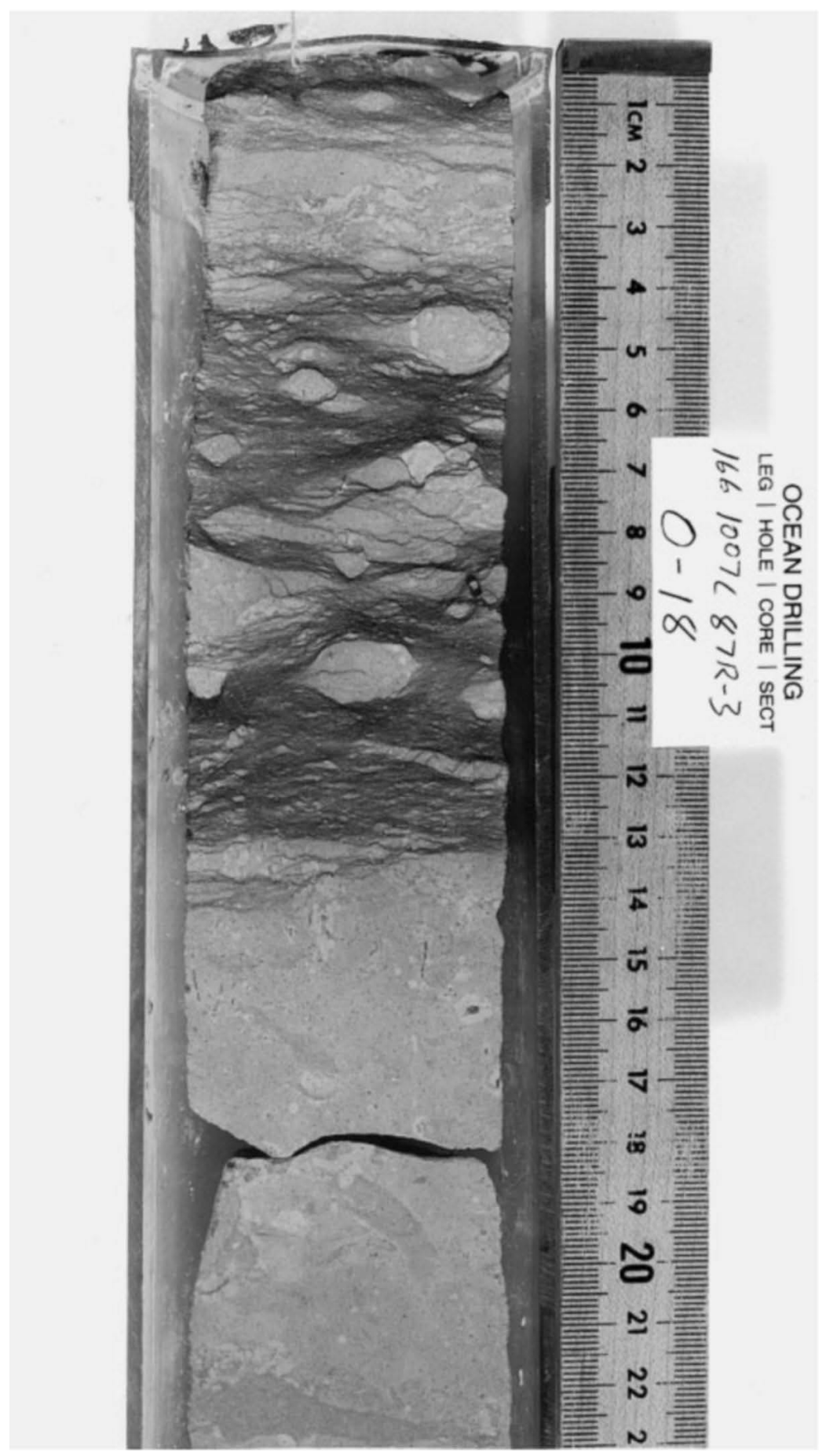

Figure 9. Wispy solution seams developed within a dark, carbonate-poor interval in Core 166-1007C-87R-3, 0-18 cm (1132.5 mbsf). Age is early Miocene.

tion was relatively minor. With depth, original burrow morphologies become increasingly deformed, and skeletal grains, commonly localized in lensoidal concentrations, are typically crushed or broken and aligned with their long axes parallel to bedding. Throughout the section, marlstones are poorly cemented (Figure 8C), and intraparticle pore space remains unfilled (Figure 8D).
At depths below $\sim 1120$ mbsf at Site 1007, compactional processes in marlstones have led to the development of dissolution seams and anastomosing stylolites, along which matrix and skeletal carbonate have been dissolved (Figure 9). Such contrasts among interbeds were not observed at Site 1006; examination of samples under the scanning electron microscope (SEM) reveals 
good textural preservation of primary carbonate components and the presence of only minor amounts of secondary cement and calcitic overgrowths on nanofossils (Figure 8E).

\section{Paleoceanography and timing of diagenesis}

Taking factors that may affect the magnitude of primary $\delta^{18} \mathrm{O}$ and $\delta^{13} \mathrm{C}$ values of sediments at any particular geographical location into account (e.g. variations in vital effects and local partitioning among marine geochemical reservoirs), stratigraphic trends in $\delta^{18} \mathrm{O}$ and $\delta^{13} \mathrm{C}$ values at Sites 1006 and 1007 are roughly consistent with the character and timing of fluctuations in isotopic records derived from the analysis of benthic foraminifera and interpreted to reflect the evolution of the Miocene ocean-climate system (Figure 7). Such similarities are particularly evident at Site 1007, where a nearly complete Miocene section was recovered. For example, the gradual decrease in $\delta^{18} \mathrm{O}$ values beginning just above the Oligocene-Miocene boundary and continuing to $\sim 15.5 \mathrm{Ma}$ (Figure 7 ) is temporally consistent with trends in Lower Miocene oxygen isotope records derived from sites in the Atlantic, Pacific and Indian Oceans, which may result from a rise in oceanic bottom water temperatures during the early Miocene (e.g. Savin et al., 1981). The progressive increase in $\delta^{18} \mathrm{O}$ values throughout the remainder of the middle Miocene and during the upper Miocene ( 15.5$9 \mathrm{Ma}$ ) at Site 1007 (Figure 7) is consistent with trends in foraminiferal records that have been attributed to the growth of ice sheets on eastern Antarctica and associated global cooling beginning in the Early Middle Miocene (Miller \& Fairbanks, 1985; Vincent \& Berger, 1985; Miller et al., 1991; Woodruff \& Savin, 1991; Flower \& Kennett, 1993). Finally, the positive excursion in $\delta^{13} \mathrm{C}$ values that occurs in the Middle Miocene section at Site 1007 (Figure 7) corresponds temporally to the well-documented Monterey Carbon Isotope Excursion, a global shift in marine $\delta^{13} \mathrm{C}$ values during the mid-Miocene that has been linked to increased storage of organic carbon in the Monterey Formation of California and phosphorite deposits of the south-eastern United States (Vincent \& Berger, 1985; Compton et al., 1990, 1993).

Although there is a temporal correspondence, the magnitude of the carbon isotope excursion recorded at Site 1007 is nearly twice that of the global signal. Whereas $\delta^{13} \mathrm{C}$ values at Site 1007 increase by nearly 2\% (Figure 7), the reported global pelagic excursion is of the order of 1\%o (Flower \& Kennett, 1993). The stratigraphic interval through which the excursion occurs is characterized at Site 1007 by an increased proportion of platform-derived components, an increase in sedimentation rate caused, in part, by an increase in turbidite deposition along the carbonate slope and an overall increase in measured aragonite concentrations (Figure 4; Eberli et al., 1997). Given that neritic carbonate components are typically enriched in ${ }^{13} \mathrm{C}$ relative to pelagic counterparts by as much as $2-5 \%$ (Milliman, 1974), these relationships suggest that the global carbon isotope excursion was augmented locally by increased input of platform-derived components to the carbonate slope. In any case, it is evident that the isotopic signature of Miocene ocean-climate evolution has been retained in the sedimentary records penetrated at Sites 1006 and 1007. As such, the retention of the global signal suggests that diagenetic processes that may have affected original isotopic compositions were active soon after deposition rather than after deep burial.

\section{Diagenetic processes}

Previous studies have demonstrated that the ooze/ chalk/limestone transition is greatly accelerated in periplatform carbonates relative to pelagic counterparts (Mullins et al., 1985; Dix \& Mullins, 1988a,b, 1992). These differences largely reflect higher sedimentation rates and increased input of metastable, platform-derived carbonate in carbonate slope settings relative to areas of pelagic deposition. Because low-Mg calcite is thermodynamically stable in deep, cold sea water, there is little drive for diagenetic alteration of pelagic ooze after deposition (Schlanger \& Douglas, 1974). As a consequence, pelagic carbonate sequences remain virtually unlithified until buried to a depth at which pressure solution releases $\mathrm{CaCO}_{3}$ that is locally reprecipitated as intraparticle fill, exterior overgrowths and intergranular cement (Garrison, 1981). Mass balance calculations demonstrate that carbonate released via pressure solution provides enough $\mathrm{CaCO}_{3}$ to account for all the cement precipitated during the gradual transformation of calcareous ooze to chalk and chalk to limestone by $\sim 200$ and $\sim 500$ mbsf respectively (Lancelot et al., 1972; Scholle, 1974; van der Lingen \& Packham, 1975; Matter et al., 1975). This process of autolithification (sensu Matter, 1974) typically imparts a trend of decreasing $\delta^{18} \mathrm{O}$ values with increasing burial depth to pelagic sequences. The decrease in $\delta^{18} \mathrm{O}$ val- 
ues reflects the precipitation of diagenetic cement at elevated burial temperatures (Scholle, 1977) and/ or from ${ }^{18} \mathrm{O}$-depleted fluids that may have interacted with clay minerals (Lawrence et al., 1979). At Site 1006, the higher primary pelagic component, the largely unlithified nature of the recovered Miocene section and near-primary isotopic signatures suggest that lithification processes at this site are similar to those observed in pelagic sequences. Given this assumption, it is likely that the present isotopic signals in the Miocene section at Site 1006 will eventually be overprinted, as diagenetic cement derived from processes of pressure solution is progressively added to the sequence during deeper burial.

Petrographic and isotopic evidence for shallowburial lithification at Site 1007, on the other hand, indicates that additional factors have controlled patterns of burial diagenesis at more proximal sites along the carbonate slope. Previous studies have demonstrated that diagenetic alteration in periplatform settings is driven primarily by differences in the solubility of aragonite, high-Mg calcite and low-Mg calcite (Schlager \& James, 1978; Mullins et al., 1985; Dix \& Mullins, 1988a,b, 1992). Whereas in monomineralic systems (i.e. pelagic sequences), diagenesis is driven primarily by extrinsic controls, such as degree of overburden, contrasting solubilities among co-existing phases in polymineralic systems provide an intrinsic drive for continued exchange between sediments and pore fluids (e.g. Lohmann, 1988). Although perhaps better documented in meteoric diagenetic settings (for a review, see James \& Choquette, 1990), appropriate conditions for mineral-driven diagenesis also occur at depth in the ocean where sea water is undersaturated with respect to aragonite and high-Mg calcite (Mullins et al., 1985). In such systems, continued dissolution of aragonite and high-Mg calcite is possible after saturation with respect to calcite is reached, because $\mathrm{Ca}^{2+}$ is maintained at a constant concentration via calcite precipitation. Rockwater exchange continues until all soluble phases are exhausted, saturation of one mineral phase is exceeded relative to other phases or the fluid exits the diagenetic system (Lohmann, 1988). As such, the rapidity and extent of this alteration process in periplatform settings depends on initial contrasts in the mineralogy of the sediment and the carbonate saturation state of sea water at the depth at which the process is occurring (e.g. Dix \& Mullins, 1988a,b, 1992).

Petrographic and isotopic evidence indicates that the extent of diagenetic alteration is not evenly distrib- uted through the section at Site 1007, but is controlled by rhythmic variation in the composition of primary sediments. Moreover, it appears that initial contrasts in sediment composition that controlled patterns of burial diagenesis have themselves been overprinted and exaggerated as a result. Initially, carbonate-rich intervals have undergone preferential cementation and calcitization, whereas adjacent carbonate-poor intervals are poorly cemented, have undergone some degree of dissolution and contain significant amounts of metastable carbonate phases. Such contrasts probably reflect differences in the diagenetic reactivity of adjacent interbeds caused by differences in the initial proportions of platform-derived carbonate (Bernet, 1999), as well as clay and organic matter that may have reduced the permeability in carbonate-poor intervals enough to inhibit reactant exchange with ambient diagenetic fluids. Thus, although the cyclic variation in $\mathrm{CaCO}_{3}$ content in the sections reflects primary depositional processes, it appears that the magnitude of $\mathrm{CaCO}_{3}$ variation at Site 1007 relative to Site 1006 (Figure 4) is largely a diagenetic phenomenon.

Porewater temperature and geochemical profiles at sites drilled during Leg 166 indicate that there is active exchange between the upper $40 \mathrm{~m}$ of the sediment column and bottom waters and suggest the presence of a downward-advecting fluid through the upper $\sim 100 \mathrm{~m}$ of the sediment column along the western margin of the GBB (Swart et al., 1996; Eberli et al., 1997). The precise mechanism involved in the flushing of the upper part of the sedimentary section is not known. However, shipboard observations are consistent with water being drawn through the platform margin as a result of density gradients between cold ocean water and geothermally heated porewaters within the carbonate platform in a manner similar to that proposed by Kohout (1967) and Simms (1984). According to this model, cold, relatively dense sea water flows into the platform and displaces warm, less dense waters in the platform interior. As this invading sea water is subsequently warmed, it is buoyed upwards, released through submarine springs and replaced by a new volume of cold seawater. Although the current lysoclines and compensation depths for high-Mg calcite and aragonite are considerably deeper than the paleodepths at Sites 1006 and 1007 (Milliman, 1975), models of variation in the average oceanic carbonate compensation depth through the Cenozoic suggest that lysoclines and compensation depths for calcite and metastable carbonates may have been con- 
siderably shallower during the Miocene (e.g. Berger et al., 1981; Delaney \& Boyle, 1988; Kump \& Arthur, 1998). Thus, assuming that thermally driven circulation processes in the GBB were active during the Miocene, the Kohout convection model provides a plausible mechanism for continuously replenishing the supply of unmodified sea water undersaturated with respect to aragonite and high-Mg calcite in contact with shallowly buried, diagenetically reactive sediment (i.e. Mullins et al., 1985). Ultimately, calcitization and the addition of diagenetic precipitates under such conditions would impart an isotopic signature on the sediment column at an early enough stage in the burial process to create an isotopic record that is roughly consistent with temporal change in sea-water chemistry associated with Miocene ocean-climate conditions. Moreover, because shallow burial alteration would greatly reduce the diagenetic reactivity and porosity of the altered intervals, associated isotopic signatures could persist for substantial lengths of time and/or to substantial burial depth.

\section{Conclusions}

Examination of mineralogical patterns and associated stable isotope signatures in Miocene sections located on the western margin of the GBB reveals that differences in the relative proportions of neritic and pelagic carbonate delivered to various sites along the carbonate slope and the cyclic nature of Miocene depositional sequences of the GBB are the primary factors that have influenced the extent of burial diagenesis and the overprinting of primary isotopic signals. Differences in the proportion of platform-derived carbonate delivered to Sites 1006 and 1007 gave rise to corresponding differences in diagenetic processes and products during burial. The section at Site 1007, located at the toe-of-slope and containing a relatively high proportion of platform-derived components, is fully lithified, and compactional processes have resulted in the development of dissolution seams below $\sim 1120$ mbsf. In contrast, the section at Site 1006, located in the Straits of Florida and containing a high proportion of pelagic carbonate, is not fully lithified until $\sim 675$ mbsf.

Primary compositional differences within and among the sections examined and their effect on diagenetic processes are reflected in isotopic data. Isoto- pic signatures associated with lithification and calcitization in the presence of cold sea water on the seafloor and at shallow burial depths at Site 1007 appear to have been unaffected by deeper burial. Given compositional similarities between deep-sea calcareous ooze and pelagic-rich sediments at Site 1006, on the other hand, it is expected that current isotopic compositions at Site 1006 will be gradually overprinted during deeper burial, as $\mathrm{CaCO}_{3}$ derived locally from pressure solution is reprecipitated as intraparticle and intergranular cement. In addition, disparity in diagenetic potential among adjacent sedimentary beds can lead to significant contrasts in lithification, porosity and the degree to which primary geochemical signatures are overprinted on small spatial scales within single sedimentary sections. Considered as a whole, isotopic and petrographic relationships in the Miocene sections examined suggest that drawing any detailed inferences from the isotopic geochemistry of ancient carbonate shelf and slope limestones requires examination of a series of sections located at various points along the carbonate slope and attention to details of intra- and intersite variation in fossil content and concentrations of carbonate, clay and organic matter. Ultimately, contrasts in isotopic signals within and among coeval sections may enhance the current understanding of the nature and volume of shallow-water carbonate production, sediment transport and margin development in ancient carbonate platform settings.

\section{Acknowledgments}

This research was supported by a grant to T. Frank from JOI-USSAC, administered by the Texas A\&M Research Foundation. This paper benefited from a review of an early version by Chris Fielding and critical reviews from J. Budd and J. Humphrey. We are also indebted to the members of the Leg 166 Shipboard Scientific Party for their assistance with sample collection. Lora Wingate (Stable Isotope Laboratory, University of Michigan), Dennis Walizer and Robert Burfield (Penn State University Stable Isotope Biogeochemistry Laboratory), Tanya Baker (Penn State University Materials Research Laboratory), and Karen Bezusko are acknowledged for technical and analytical support. 


\section{Bibliography}

Arthur, M. A. \& Dean, W. E. (1991) A holistic geochemical approach to cyclomania: examples from Cretaceous pelagic limestone sequences. In: Cycles and Events in Stratigraphy (Eds. E. Einsele, W. Ricken and A. Seilacher), pp. 126-166. SpringerVerlag, Berlin.

Arthur, M. A., Dean, W. E., Bottjer, D., \& Scholle, P. (1984) Rhythmic bedding in Mesozoic-Cenozoic pelagic carbonate sequences: The primary and diagenetic origin of Milankovitch-like cycles. In: Milankovitch and Climate: Understanding the Response to Astronomical Forcing (Eds. A. L. Berger, J. Imbrie, J. D. Hays, et al. ), NATO ASI Series C: Math. Phys. Sci., 126, 191-222.

Berger, W. H., Vincent, E., \& Thierstein, H. R. (1981) The deep-sea record: Major steps in Cenozoic ocean evolution. In: The Deep Sea Drilling Project: a Decade of Progress (Eds. J. E. Warme, R. G. Douglas and E. L. Winterer), Spec. Publ. Soc. Econ. Paleont. Miner., 32, 489-504.

Berggren, W. A., Kent, D. V., Swisher, C. C., \& Aubry, M.-P. (1995) A revised Cenozoic geochronology and chronostratigraphy. In: Geochronology, Times Scales and Global Stratigraphic Correlation (Eds. W. A. Berggren, D. V. Kent, M.-P. Aubry and J. Hardenbol), Soc. Econ. Paleont. Miner. Spec. Publ., 54, 129-212.

Bernet, K. (1999) The Record of Hierarchies of Sea Level Fluctuations in Cores. Logs, and Seismic Data Along the Great Bahamas Bank Transect. PhD Dissertation, University of Miami, Coral Gables, FL, 205 pp.

Compton, J. S., Snyder, S. W., \& Hodell, D. A. (1990) Phosphogenesis and weathering of shelf sediments from the southeastern United States: Implications for Miocene $\delta^{13} \mathrm{C}$ excursions and global cooling. Geology, 18, 1227-1230.

Compton, J. S., Hodell, D. A., Garrido, J. R., \& Mallinson, D. J. (1993) Origin and age of phosphorite from the south-central Florida Platform: Relation of phosphogenesis to sea-level fluctuations and $\delta^{13} \mathrm{C}$ excursions. Geochim. Cosmochim. Acta, 57, 131-146.

Cotillon, P. (1991) Varves, beds, and bundles in pelagic sequences and their correlation (Mesozoic of SE France and Atlantic). In: Cycles and Events in Stratigraphy (Eds. G. Einsele, W. Ricken and A. Seilacher), pp. 820-839. Springer-Verlag, Berlin.

Cotillon, P. \& Rio, M. (1984) Cyclic sedimentation in the Cretaceous of Deep Sea Drilling Project Sites 535 and 540 (Gulf of Mexico), 534 (central Atlantic), and in the Vocontian Basin (France). Init. Rep. Deep Sea Drilling Proj., 77, 339-376.

Dean, W. E. \& Arthur, M. A. (1987) Inorganic and organic geochemistry of Eocene-Cretaceous strata recovered from the lower continental rise, North American Basin, Site 603 Deep Sea Drilling Program Leg 93. Init. Rep. Deep Sea Drilling Proj., 93, 1093-1137.

Dean, W. E. \& Gardner, J. V. (1982) Origin and geochemistry of redox cycles of Jurassic to Eocene age, Cape Verde Basin (DSDP Site 367), continental margin of North-west Africa. In: Nature and Origin of Cretaceous Carbon-Rich Facies (Eds. S. O. Schlanger and M. B. Cita), pp. 55-78. Academic Press, New York.

Dean, W. E., Gardner, J. V., Jansa, L. F., Cepek, P. \& Seibold, E. (1978) Cyclic sedimentation along the continental margin of Northwest Africa. Init. Rep. Deep Sea Drilling Proj., 41, 965-986.
Delaney, M. L. \& Boyle, E. A. (1988) Tertiary paleoceanic chemical variability; unintended consequences of simple geochemical models. Paleoceanography, 3, 137-156.

Dix, G. R. \& Mullins, H. T. (1988a) A regional perspective of shallow-burial diagenesis of deep-water periplatform carbonates from the northern Bahamas. Proc. ODP Sci. Results, 101, 279-302.

Dix, G. R. \& Mullins, H. T. (1988b) Rapid burial diagenesis of deep-water carbonates: Exuma Sound, Bahamas. Geology, 16, 680-683.

Dix, G. R. \& Mullins, H. T. (1992) Shallow-burial diagenesis of deep-water carbonates, northern Bahamas: Results from deepocean drilling transects. Geol. Soc. Am. Bull., 104, 303-315.

Eberli, G. P. \& Ginsburg, R. N. (1989) Cenozoic progradation of northwestern Great Bahama Bank, a record of lateral platform growth and sea-level fluctuations. In: Controls on Platform and Basin Development (Eds. P. D. Crevello, J. L. Wilson, J. F. Sarg, and J. F. Read), Soc. Econ. Paleont. Miner. Spec. Publ., 44, 339-351.

Eberli, G. P., Swart, P. K., \& Malone, M. J., et al . (1997) Proc. ODP, Init. Rep., 166, 850 pp. College Station, TX (Ocean Drilling Program).

Einsele, G. (1982) General remarks about the nature, occurrence, and recognition of cyclic sequences (periodites). In: Cyclic and Event Stratification (Eds. G. Einsele and A. Seilacher), pp. 3-7. Springer-Verlag, Berlin.

Flower, B. P. \& Kennett, J. P. (1993) Middle Miocene ocean-climate transition: High-resolution oxygen and carbon isotopic records from Deep Sea Drilling Project Site 588A, southwest Pacific. $\mathrm{Pa}$ leoceanography, 8, 811-843.

Frank, T. D. (2000) Data report: Inorganic geochemistry of Miocene sediments, Sites 1006 and 1007, leeward margin, Great Bahama Bank. Proc. ODP Sci. Results, 166, 137-143.

Friedman, I. \& O'Neil, J. R. (1977) Compilation of stable isotope fractionation factors of geochemical interest. In: Data of Geochemistry (Ed. M. Fleischer), US Geol. Surv. Prof. Paper, 440KK, 12 pp.

Garrison, R. E. (1981) Diagenesis of oceanic carbonate sediments: a review of the DSDP perspective. In: The Deep Sea Drilling Project: a Decade of Progress (Eds. J. E. Warme, R. G. Douglas, and E. L. Winterer), Soc. Econ. Paleont. Miner. Spec. Publ., 32, 181-207.

Graham, D. W., Corliss, B. H., Bender, M. L., \& Keigwin, L. D. (1981) Carbon and oxygen isotopic disequilibria of Recent benthic foraminifera. Mar. Micropaleontol., 6, 483-497.

Hendry, J. P., Trewin, N. H., \& Fallick, A. E. (1996) Low-Mg calcite marine cement in Cretaceous turbidites; origin, spatial distribution and relationship to seawater chemistry. Sedimentology, 43, 877-900.

James, N. P. \& Choquette, P. W. (1990) Limestones - the sea floor diagenetic environment. In: Diagenesis (Eds. I. A. McIlreath and D. W. Morrow), Geosci. Can. Reprint Ser., 4, 13-34.

Jansa, L. F., Enos, P., Tucholke, B. E., Gradstein, F. M., \& Sheridan, R. E. (1979) Mesozoic-Cenozoic sedimentary formations of the North American Basin, western North Atlantic. In: Deep Drilling Results in the Atlantic Ocean: Continental Margins and Paleoenvironment (Eds. M. Talwani, W. W. Hay, and W. B. F. Ryan), Maurice Ewing Ser., 3, 1-48. 
Kohout, F. A. (1967) Ground-water flow and the geothermal regime of the Floridian Plateau. Trans. Gulf Coast Assoc. Geol. Soc., 17, 339-354.

Kump, L. R. \& Arthur, M. A. (1998) Global chemical erosion during the Cenozoic: weatherability balances the budgets. In: Tectonic Uplift and Climate Change (Ed. W. F. Ruddiman), pp. 400426. Plenum Press, New York.

Lancelot, Y., Hathaway, J. C., \& Hollister, C. D. (1972) Lithology of sediments from the western North Atlantic, Leg 11. Init. Rep. Deep Sea Drilling Proj., 11, 901-949.

Lawrence, J. R., Drever, J. I., Anderson, T. F., \& Brueckner, H. K. (1979) Importance of alteration of volcanic material in the sediments of Deep Sea Drilling Site 323; chemistry, ${ }^{18} \mathrm{O} /{ }^{16} \mathrm{O}$ and ${ }^{87} \mathrm{Sr} /{ }^{86} \mathrm{Sr}$. Geochim. Cosmochim. Acta, 43, 573-588.

Lohmann, K. C. (1988) Geochemical patterns of meteoric diagenetic systems and their application to studies of paleokarst. In: Paleokarst (Eds. N. P. James and P. W. Choquette), pp. 58-80. Springer-Verlag, New York.

Malone, M. J., Baker, P. A., Burns, S. J., \& Swart, P. K. (1990) Minor element and stable isotopic composition of the carbonate fine fraction: Site 709, Indian Ocean. Proc. ODP Sci. Results, 115, 661-676.

Matter, A. (1974) Burial diagenesis of pelitic and carbonate deep sea sediments from the Arabian Sea. Init. Rep. Deep Sea Drilling Proj., 23, 421-470.

Matter, A., Douglas, R. G., \& Perch-Nielsen, K. (1975) Fossil preservation, geochemistry and diagenesis of pelagic carbonates from Shatsky Rise, northwest Pacific. Init. Rep. Deep Sea Drilling Proj., 32, 891-922.

Mazzullo, S. J. (1994) Lithification and porosity evolution in Permian periplatform limestones, Midland Basin, Texas. Carbonates Evaporites, 9, 151-171.

Melim, L. A., Swart, P. K.. \& Maliva, R. G. (1995) Meteoric-like fabrics forming in marine waters; implications for use of petrography to identify diagenetic environments. Geology, 23, 755-758.

Miller, K. G. \& Fairbanks, R. G. (1985) Oligocene to Miocene carbon isotope cycles and abyssal circulation changes. In: The Carbon Cycle and Atmospheric $\mathrm{CO}_{2}$ : Natural Variations Archean to Present (Eds. E. T. Sundquist and W. S. Broecker), Am. Geophys. Union Geophys. Monogr. Ser., 32, 469-486.

Miller, K. G., Wright, J. D., \& Fairbanks, R. G. (1991) Unlocking the ice house: Oligocene-Miocene oxygen isotopes, eustasy and margin erosion. J. Geophys. Res., 96, 6829-6848.

Milliman, J. D. (1974) Marine Carbonates. Springer-Verlag, Berlin.

Milliman, J. D. (1975) Dissolution of aragonite, Mg-calcite and calcite in the North Atlantic Ocean. Geology, 3, 461-462.

Mullins, H. T., Wise, S. W., Gardulski, A. F., Hinchey, E. J., Masters, P. M., \& Siegel, D. I. (1985) Shallow subsurface diagenesis of Pleistocene periplatform ooze; northern Bahamas. Sedimentology, 32, 473-494.

Ricken, W. (1992) A volume and mass approach to carbonate diagenesis: the role of compaction and cementation. In: Diagenesis III (Eds. K. H. Wolf and G. V. Chilingarian), Developments in Sedimentology, 47, pp. 291-315. Elsevier Science, New York.
Savin, S. M., Douglas, R. G., Keller, G., Killingley, J. S., Shaughnessy, L., Sommer, M. A., Vincent, E., \& Woodruff, F. (1981) Miocene benthic foraminiferal isotope records: A synthesis. Mar. Micropaleontol., 6, 423-450.

Schlager, W. \& James, N. P. (1978) Low-magnesian calcite limestone forming at the deep-sea floor, Tongue of the Ocean, Bahamas. Sedimentology, 25, 675-702.

Schlanger, S. O. \& Douglas, R. G. (1974) The pelagic-ooze-chalklimestone transition and its implications for marine stratigraphy. In: Pelagic Sediments on Land and Under the Sea (Eds. K. J. Hsü and H. C. Jenkyns), Int. Assoc. Sedimentol. Spec. Publ., 1, 117-148.

Scholle, P. A. (1974) Diagenesis of Upper Cretaceous chalks from England, Northern Ireland and the North Sea. In: Pelagic Sediments on Land and Under the Sea (Eds. K. J. Hsü and H. C. Jenkyns), Int. Assoc. Sedimentol. Spec. Publ., 1, 177-210.

Scholle, P. A. (1977) Chalk diagenesis and its relation to petroleum exploration: Oil from chalks, a modern miracle? AAPG Bull., 61, 982-1009.

Shackleton, N. J. \& Opdyke, N. D. (1973) Oxygen isotope and palaeomagnetic stratigraphy of equatorial Pacific core V28-238: Oxygen isotope temperatures and ice volumes on a $10^{5}$ and $10^{6}$ year scale. Quatern. Res., 3, 39-55.

Simms, M. (1984) Dolomitization by groundwater flow systems in carbonate platforms. Trans. Gulf Coast Assoc. Geol. Soc., 34, 411-420.

Swart, P. K. \& Burns, S. J. (1990) Pore-water chemistry and carbonate diagenesis in sediments from Leg 115: Indian Ocean. Proc. ODP Sci. Results, 115, 629-646.

Swart, P. K. \& Guzikowski, M. (1988) Interstitial-water chemistry and diagenesis of periplatform sediments from the Bahamas, ODP Leg 101. Proc. ODP Sci. Results, 101, 363-380.

Swart, P. K., Eberli, G. P., DeCarlo, E. H., Kramer, P., Nagihara, S., \& Malone, M. (1996) Fluid flow in the margin of Great Bahama Bank; evidence from interstitial water chemistry of pore waters collected during Leg 166. Geol. Soc. Am., Program with Abstracts, $28,43-43$.

van der Lingen, G. J. \& Packham, G. H. (1975) Relationships between diagenesis and physical properties of biogenic sediments of the Ontong-Java Plateau (Sites 288 and 289, Deep Sea Drilling Project). Init. Rep. Deep Sea Drilling Proj., 30, 443-481.

Vincent, E. \& Berger, W. H. (1985) Carbon dioxide and polar cooling in the Miocene: the Monterey Hypothesis. In: The Carbon Cycle and Atmospheric $\mathrm{CO}_{2}$ : Natural Variations Archean to Present (Eds. E. T. Sundquist and W. S. Broecker), Am. Geophys. Union Geophys. Monogr. Ser., 32, 455-468.

Westphal, H. (1998) Carbonate Platform Slopes-A Record of Changing Conditions. Lecture Notes in Earth Sciences, 75. Springer-Verlag, New York.

Woodruff, F. \& Savin, S. M. (1991) Mid-Miocene isotope stratigraphy in the deep sea: High-resolution correlations, paleoclimatic cycles, and sediment preservation. Paleoceanography, 6, 755-806. 